УДК 811.111'37

https://doi.org/10.33989/2524-2490.2020.33.228244

ВІКТОРІЯ КРАВЧЕНКО

ORCID 0000-0002-3837-3203

(Полтава) (Poltava)

Place of work: Poltava V. G. Korolenko National Pedagogical University

Country: Ukraine

Email:

\title{
THE CONCEPT OF UNITED EUROPE IN ITS IDEOLOGICAL VERBALIZATION IN THE EUROPEAN INTEGRATION POLITICAL DISCOURSE
}

Важливими чинниками, що вплинули на формування нової європейської иіннісної системи й створили ї̈ своєрідність, є політичні зміни в Європі, поява хінгвістичного концепту НОВА ЄВРОПА (New Euгоре) та створення нової моделі європейського суспільства. У статті було зроблено спробу окреслити систему иінностей об'єднаної Європи кіния ХХ - початку XXI ст., на основі якої формуеться нова ідеологія в досліджуваному дискурсі, а також вивчити ті лексичні засоби, щео відображують изю ідеологію. Цю статтю присвячено розгляду нової ідеології Об'єднаної Європи. Аналіз засвідчуе, щзо иял ідеологія формується за допомогою дискурсивних засобів. Вона базуеться на опорному змістовопонятійному блоциі «спільних иุінностей», який реалізується за допомогою кількох стійких словосполучень, натомість поняття «европейська інтеграціля, «європейська ідентичність», «розширення» мають порівняно вужчий репертуар лексичного вираження.

Ключові слова: концепт; дискурс; політичний дискурс; ідеологія; Об'єднана Европа.

The political relationship modernization, the modern society democratization, and the political movement of the integration processes led to the mental space changes. The problem of the present and the future "NEW EUROPE" and the European association is taken under special research in different scientific spheres: political science, sociology, philosophy, and cognitive linguistics, etc. The correlation of language and social reality, language and ideology is taken under constant attention in modern linguistics. The actual direction of the researches in this sphere is political discourse analysis.

One of the peculiarities of this problem is the fact that the new subjects for the linguistics study are formed under the influence of social changes. These subjects demand special consideration. The European integration's processes, which form the complex of important sociolinguistics' consequences, are also giving rise to the new kinds of political discourse, which is widely accessible due to the development of the Internet.

The question about the nature and the function of the concept of NEW EUROPE leads us to the understanding of the "European identity", Enlargement, the future, and the past of Europe.

The new ideology of the UNITED EUROPE that is formed with the help of European integration political discourse has a complex structure of several substantial blocs. The analyzed material has proved that the main blocks are "common values", "European integration" and "enlargement". So let's study these blocs thoroughly focusing attention on the ways of lexical means that represent certain contexts. 
The key problem for the new European integration discourse is the new value system, which is formed inside this discourse. In the first place, we are interested in the representation of the common value system. The values are the phenomenon, which is estimated by a certain group, which is "good", "right", "embodying an example".

The value analysis, according to (Karasik, 1996) is based on the cultural concepts modelling, the main component of which is the value component. Due to that, we can determine the value conceptual network of a certain community. The political ideology of a democratic western world is used as a certain common system of liberal values - freedom, equality, justice, etc. Besides, each society has its own set of values. There are specifically national concepts also known as keywords or key notions (Belova, 2002), which represent the national mentality specifics. As a vivid example of such concepts, states (Belova, 2002), are the concepts of the British culture as privacy, gentleman, home, island, Anglocentrism, monarchy...In the American culture such concepts can be named - American Dream, individualism, melting pot, democracy. For example: "We believe in British values. Freedom. Justice. Fairness. But we don't accept that those are values for Britain alone".

The cardinal changes in the social life lead to the ruin of the conceptual network and the change of the value system. According to this statement, (Stepin, 1992, p. 49) follows that "the main and really epoch-making change in the value system deals with the new system rises. The value is considered to be the innovation, originality and just new". As a result, the concept of novelty is given the status of value, which is widely used in the European integration political discourse.

The main facts that have influenced the forming of the new European value system and formed its peculiarities are the political changes in Europe, the new concept NEW EUROPE appearance, and the creation of a new European community model. In this paper, we outline the value system of United Europe at the beginning of the 21st century on which the new ideology is based. Much attention is given to the study of the lexical representation of the UNITED EUROPE ideology. The topic of values is one of the principles in the European integration discourse. The lexeme "values" gains the status of a certain keyword that is varied by the different ways of acting in the function of the main identification feature of the new European community as a community of values. New Europe is above all a community of values. Europe has spread these values throughout the world. Also, compare: "Europe's constitution should recognize and embrace the values that underpin a fair society".

We came to the conclusion that the new ideology is based on the fact that the value system should be taken the main place in New Europe, that this value system is spread on the whole world. This value system is based on the value of the past, or the traditional European values, and also on the new values connecting with a future. So we can observe the integration of traditional values (self-help, tolerance, belief in strong community and society, family, home, freedom, the rule of law, fairness, justice, peace with the new values, as solidarity, equal opportunities for all, human rights and the protection minorities, integration, new community). The wildly functioning of these lexemes is a particularity of modern political discourse. This is proving Fomenko thought (1998: 4) that the language representation of the universal values just as national concepts are changed in the political discourse.

As the researchers notice, in Ancient times nomination Europe was just a geographical term, which hadn't cultural or political connotations. Then this term slowly turned into a notation of the spiritual Christianity sphere. This wording of Europe and the European Union is observing in the analyzing texts when the definition is constructed with the help of combination Christian values: "The EU is a community with Christian values". 
One of the most important combinations which are used to determine the European values are common values, which lead us to the significant concept of "common values" in the ideology of a new united Europe. This concept sometimes identifies with the "western values" - "In the first place, Europe's commitment to democracy, the rule of law, justice and human rights can hardly be said to be distinctive; these are core Western values as fiercely held in America as in Europe". The notion of shared values sometimes acts as a variant to determine the common values. This is typical for the contexts in which the cultural variety of Europe is emphasized: "Europe is a continent with many traditions and languages, but also with shared values".

Some contexts prove that common values are synonyms to European values, for example: “The European values should capture the public's aspiration: a better balance between work and family, combining growth with environmental well-being and achieving economic dynamism with social cohesion".

The analyzed texts make it clear that an essential component of the new ideology of a united Europe is a positively evaluated set of economic characteristics, such as prosperity and wealth. This fact has proved Javorskaya's assumption (Javorskaya, 2005: 86) that the new European identity of EU citizens is largely instrumental, and a common sense of economic security in terms of identification can be no less important than the commonality of culture. For example, the leading place in the system of basic social values of European society, as well as British, according to OV Gorodetskaya, belongs to prosperity (Gorodetskaya 2002, p. 88). The concept of wealth is one of the components of this system.

Besides the EU has a certain set of universal values on which the new society is based. This set is marked with the help of attribute constructions as in the previous examples and with the help of genitive constructions with the preposition of (the values of...) - human dignity, solidarity, freedom, equality, safety, security, reliability, justice, democracy, rule of low. For example: "Conscious of its history and its spiritual and moral heritage, Union found on the indivisible universal values of human dignity, freedom, equality, and solidarity, it's based on the principles of democracy and the rule of law. It places the individual at the heart of its activities, by establishing the citizenship of the Union and creating an area of freedom, security, and justice".

For the European integration discourse, the concept of integration (European integration) is important from the point of view of forming the new ideology. I can affirm that because the economical and political process of the unity of European society is in the basement of the EU creation: "But throughout the process, integration has been driven forward by the inherent dynamics of market opening, of deepening economic interdependence and of continuous political engagement in common institutions". The basics of integration are considered to be solidarity and competition (the last is considered to be a unification means): "European integration is based on solidarity among the Member States but also on the competition; Therefore, competition and solidarity are to be seen as mutually dependent elements of the "European model"".

The concept of "European integration" is an ideological kernel of the studied discourse, and this is not only its conceptual component but a certain marker of belonging to some certain ideological system. To such markers, we should refer the following concepts as "Enlargement" and "European identity".

The fact that the concept "Enlargement" belongs to the ideology in the European integration discourse is proved by the contexts: "Europe is expanding. Instead of being 15 countries, we are going to be 25 . That will mean fundamental changes in the way that Europe works. This will be from now on in a fundamentally different Europe"; "The boost 
given to Community integration is now having the effect of prompting a vast enlargement process to include countries of central and eastern Europe"; "Enlargement will change the shape of New Europe". I'd like to stress the idea, that the main problem of the European integration is "enlargement" as the authors of the studding discourse note it. Enlargement is a basic way to achieve the Eurointegration ultimate aim - Europe unification: "All existing member states agree that enlargement is a dominant issue. In particular, the addition of central and eastern European countries would bring a symbolic - and belatedclose to the continent's Cold War divisions".

One more important moment in the determination of the new ideology of the European integration discourse specifics is the European society's aspiration to find a new European identity. This concept and the nominations connected with it are the basis for the uniting ideology, so European identity is normally connected with the verbs to unite, to join, the noun entity in the contexts. The semantics of the words listed above has a socalled "unite" the component. For example: "We reject the narrow view of a European reunification based solely on economic terms. To successfully unite eastern and western traditions, we believe it is necessary to fully and objectively express the European identity in order to build it on a basis of recognized and shared values"; "There is such an entity as European identity, there should be no fears about joining European Union".

The examined nominations enable tracing the forming and functioning mechanism of a new "United Europe" ideology. The analysis has proved that this ideology is forming with the help of discourse means. It is based on the supporting conceptual bloc "common values", which is realized with the help of state constructions or the concepts of "European integration", "European identity", "enlargement" that have a rather narrow repertory of lexical representation.

\section{СПИСОК ВИКОРИСТАНИХ ДЖЕРЕ $Д$}

Белова А. Д. Языковые картины мира в рамках когнитивно-дискурсивной парадигмы. Проблемь современной социчолингвистики и фонологии / Таврический нац. ун-т. 2002. № 29. C. 17-23.

Городецька О. В. Національно-марковані концепти в Британській мовній картині світу XX століття : дис. ... канд. філол. наук : 10.02.04. Київ, 2002. 182 с.

Идентичность Европы: вопросы, позиции, перспективы. Идеи европеизма во второй пол. ХХ века : реф. сб. / под ред. Ю. А. Гусарова. Москва : ИНИОН РАН, 2000. С. 10-43.

Карасик В. И. Культурные доминанты в языке. Языковая личность: культурные концепты : сб. науч. тр. Волгоград ; Архангельск : Перемена, 1996. С. 3-16.

Степин В. С. Философская антропология и философия науки. Москва : Высшая школа, 1992. $191 \mathrm{c}$.

Фоменко О. С. Лінгвістичний аналіз сучасного політичного дискурсу США (90-ті роки XX ст.) : автореф. дис. ... канд. філол. наук : 10.02.04. Київ, 1998. 17 с.

Яворська Г. М. Дискурс та ідентичність. Ісламська ідентичність в Украӥні / О. В. Богомодов, С. І. Данилов, I. М. Семиволос, Г. М. Яворська. Київ : AMES, 2005. С. 80-101.

\section{VIKTORIIA KRAVCHENKO}

\section{THE CONCEPT OF UNITED EUROPE IN ITS IDEOLOGICAL VERBALIZATION IN} THE EUROPEAN INTEGRATION POLITICAL DISCOURSE

The problem of the present and the future "EUROPE" and the European association is taken under special linguistic research. This paper focuses on the ideology representation with the help of the concept of UNITED EUROPE, which is formed in the European integration political discourse and has a complex structure. The central concept EUROPE that forms the new ideology is being gotten the deep metaphoric comprehension. The analyzed material has proved that this discourse consists of a variety of blocks while 
the main blocks are "common values", "European integration" and "enlargement". The article gives a detailed analysis of universal values on which the new European society is based. The ideology of the UNITED EUROPE and the ways of its linguistic representation in the European integration political discourse were distinguished.

Key words: concept; discourse; political discourse; ideology; United Europe.

\section{REFERENCES}

Belova, A. D. (2002). Jazykovye kartiny mira v ramkah kognitivno-diskursivnoj paradigmy [Linguistic pictures of the world within the framework of the cognitive-discursive paradigm]. Problemy sovremennoi sociolingvistiki i fonologii [Problems of modern sociolinguistics and phonology]. Tavricheskii nacional'nyi universitet [Tavricheskiy National University], 29, 17-23 [in Russian].

Fomenko, O. S. (1998). Linhvistychnyi analiz suchasnoho politychnoho dyskursu SShA (90-ti roky XX st.) [Linguistic analysis of modern US political discourse (90s of the twentieth century)]. (Extended abstract of PhD diss.). Kyiv [in Ukrainian].

Horodetska, O. V. (2002). Natsionalno-markovani kontsepty v Brytanskii movnii kartyni svitu XX stolittia [National-labeled concepts in the British linguistic picture of the world of the twentieth century] (PhD diss.) Kyiv [in Ukrainian].

Identichnost Evropy: voprosy, pozicii, perspektivy [Identity of Europe: questions, positions, perspectives]. (2000). In Ju. A. Gusarov (Ed.), Idei evropeizma vo vtoroj pol. XX veka [Ideas of Europeanism in the second half of the XX century] : ref. col. (pp. 10-43). Moskva: INION RAN [in Russian].

Karasik, V. I. (1996). Kulturnye dominanty v iazyke [Cultural dominants in the language] Jazykovaja lichnost: kulturnye koncepty [Linguistic personality: cultural concepts] : coll. of scientific works (pp. 3-16). Volgograd; Arhangelsk: Peremena [in Russian].

Stepin, V.S. (1992). Filosofskaja antropologija i filosofija nauki [Philosophical anthropology and philosophy of science]. Moskva: Vysshaja shkola [in Russian].

Yavorska, H. M. (2005). Dyskurs ta identychnist [Discourse and identity]. In Bohomolov O. V., Danylov S. I., Semyvolos I. M., \& Yavorska H. M. Islamska identychnist v Ukraini [Islamic identity in Ukraine] (pp. 80-101). Kyiv: AMES [in Ukrainian].

Отримано 27.11.2020 p. 